\title{
Application of the Contour Method to Determine Axial Residual Stresses in Cold Extruded Steel Rods
}

O. Aydin
Graduate
Dortmund Technical University
Faculty of Mechanical Engineering
Germany
C. Simsir
Assoc. Prof. Dr.
Middle East Technical University
Faculty of Engineering
Metallurgical and Materials Engineering
Turkey

\section{INTRODUCTION}

In a forward cold extrusion process, raw material is pushed through a die at low temperatures and gains shape. The process possesses a wide range of applications in developed industries to produce hollow or full cylindrical products such as heat exchangers, screws, bolts, etc. $16 \mathrm{MnCr} 5$ alloy used for cold extrusion in the present study is one of the preferred materials for the process since it has desirable combined properties of very good machinability and workability with reasonable strength due to strain hardening after plastic deformation. During a cold extrusion process, material undergoes inevitably inhomogeneous plastic deformation that causes long-range residual stresses (macro residual stresses) due to misfits between neighbour regions $[1,2]$. While compressive residual stresses are believed to increase the durability of a component, tensile residual stresses are commonly anticipated to lower the lifespan of components [3, 4]. Moreover, residual stresses may affect the dimensional stability detrimentally during the implementation of the subsequent manufacturing processes such as cutting operations. However, the experimental evaluation of axial residual stresses in the massive and cylindrical products is impossible or arduous and achieved only with a few methods owing to its thickness (diameter) and cylindricity. Many of residual stress measurement

Received: May 2021, Accepted: August 2021

Correspondence to: O. AYDIN

Faculty of Mechanical Engineering

Technical University of Dortmund, Germany

E-mail: oguzhan.aydin@tu-dortmund.de

doi:10.5937/fme2104941A

(C) Faculty of Mechanical Engineering, Belgrade. Allrights reserved methods such as X-ray diffraction, hole drilling, ultrasonic and magnetic methods are employed to cha-racterize residual stresses (rs) in thinner components. Due to the requirement of strain gauge, the implementation of the crack compliance method would require a circumferential cut which is not possible with long wire used in wire electro-discharge machining process. Except these, the methods that are based on indentation tests use various types of indenters and indentation tests for the prediction of residual stresses [5, 6]. These methods require knowledge of some mechanical properties and inverse calculation for residual stress prediction $[7,8]$. Furthermore, part size and shape restrict the application of some methods such as ring core, deep hole drilling and sectioning methods. Beside these facts, the contour method brings the invaluable benefit that the variation in axial residual stresses in a component can be determined all over cut cross-section. Those residual stresses can be measured by high-energy (HE) X-ray and neutron diffraction methods. However, the facilities of these methods are costly and inaccessible to some of their potential users.

The contour method introduced at the very beginning of the 21 st century includes performing a straight cut that will lead to the relaxation of residual stresses on the cut surface [9]. The release of residual stresses on new free surfaces results in elastic deformation which will be measured subsequently. In accordance with the superposition principle, forcing the elastically deformed surface to its initial state requires the reverse of preexisting stresses [10]. Shear stresses in cutting plane together with normal stress contribute to elastic deformation. However, calculating average deformation of opposite surfaces mitigates the effect of shear stresses as 
well as cutting-induced errors and roughness [11, 12]. At the end, the finite element (FE) model in which the average deformation of opposite surfaces (free surfaces after cut) serves as displacement boundary condition is constructed for the evaluation of residual stresses as the last procedure of the contour method [9].

Wire electro-discharge machining (wire-EDM), which is ideal for the contour method discharges electric current by means of thin wire to electrically conductive workpiece in pure water environment. As no extreme contact or cutting force is exerted on workpiece, wireEDM can be considered to be a plausible method for cutting process to make residual stresses to release without distorting elastic deformation which is in the range of only a few micrometres [9]. However, it must be noted that wire-EDM can still introduce some amount of error owing to bulge effect and other distortions such as plastic deformation and wire breakage. However, prior studies prove that adequate clamping and appropriate cutting parameters reduce the cuttinginduced errors and plastic deformation very significantly during the cutting process in the contour method, $[11,12]$.

Another tool used in the current study to assess residual stress generated by cold extrusion is FE simulation of the full extrusion process (extrusion and ejection). Although setting up a FE simulation for the prediction of press load is relatively simple, setting up a simulation for the prediction of residual stresses requires further considerations [13]. In addition to the movement of punch pushing initial material through die, ejection step which is following press time and alters the distribution of axial residual stresses must be modelled [14]. Furthermore, a highly accurate hardening curve should be supported with numerical procedures that will not induce significant inaccuracies. Finally, the elastic properties (Young's modulus and Poisson's ratio) of die must be modelled to be able to observe the consequences of the elastic deformation of die on workpieces and residual stresses when punch is retracted [14].

The measurement of the surface contour after wireEDM cutting and the processing of the acquired data are important steps in the application of the contour method $[15,16]$. Although the most studies use tactile or laser CMMs (coordinate measuring machine) for the surface contour measurement, the contour is measured by highly accurate focus variation optical microscope in this study. Afterwards, the data acquired was processed in MatLab ${ }^{\circledR}$ software and stress calculation with fit curve are performed using FE package MSC.Marc /Mentat ${ }^{\circledR}$ for linear elastic FE model as the contour method requires in its last step.

In this study, the contour method is applied to cold forward extruded parts having different area reductions and the effect of deformation level on the axial residual stresses is investigated. The contour method was previously applied to the samples of hot extruded titanium alloy and stress-relieved aluminium alloy (using hand forging) with other different shapes rather than cylindric in both studies $[17,18]$. To the best of the authors' knowledge, the present paper is the first attempt of application of the contour method to cold extruded products without any post-process and full cylindrical thick products. Aside from this, this study is also the sole study that includes very high accurate contour measurement with the focus variation optical microscopy. This may be great of importance since deformations in few micrometres range cause measurable stresses. The results indicate that contour the method provides a preferable alternative for the evaluation of axial residual stresses in cold extruded cylindrical parts.

Even though only a 2D residual stress map is aimed to be found in the current work, the recent developments of the contour method which allow the evaluation of more than one component of stress tensor exist. To give an example to these studies, inherent strains produced in a continuous process are used to calculate multi-axial stresses performing multiple cuts in three perpendicular directions $[19,20]$. Without continuous process assumption, multiple components of residual stresses are obtained using superposition principle and multiple cuts [21]. Multiple components of stress tensor are obtained performing a single straight cut and additional surface measurements [22].

The rest of the article is organized as follows: The details of the experimental procedure for the contour method are presented in Section 2, while the details of data processing and the application of the deformation curve in linear elastic finite element analysis (FEA) using MSC Marc/Mentat ${ }^{\circledR}$ (the last procedure of the contour method) are available in Section 3. Section 4 is dedicated to the implementation of FE simulations of the full extrusion process (pressing and ejection) with commercial package Abaqus ${ }^{\circledR}$. Both experimental and simulations results are presented in Section 5. Finally, Section 6 provides the summary of the study with an outlook for future research.

\section{PREPARATION OF SPECIMENS}

DIN/EN $16 \mathrm{MnCr} 5$ steel billets in the size of $25 \times 25 \mathrm{~mm}$ (diameter $x$ height) as shown in Figure 1(a) are extruded to specimens illustrated in Figure 1(b) in the true strains, $\ln \left(\mathrm{A}_{\text {initial }} / \mathrm{A}_{\text {final }}\right)$ of $0.7,1.0$ and 1.4 at room temperature using a D-frame eccentric crank press. Here, true strain refers to actual strain found by the simple logarithmic calculation. Two specimens from the same initial diameter workpieces are produced for the investigation of each true strain which is summarized together with corresponding extrusion ratios in Table 1. All the billets provided from the same manufacturer are delivered in normalized condition after cold drawing and they are lubricated with the lubricant, $\mathrm{MoS}_{2}$. Cold drawing is a process in which the diameter of a bar is reduced and raw material is pulled. Normalizing heat treatment applied to cold-formed material includes heating the workpiece to high temperatures and moderately slow cooling to room temperature in order for gaining ductility and more uniform microstructure. The cooling process for $16 \mathrm{MnCr} 5$ is generally performed in air atmosphere after heating up materials to $950{ }^{\circ} \mathrm{C}$ leading to stress relief of cold working and finer microstructure compared to annealing process [23].

The chemical composition of the alloy defined in the standards is shown in Table 2 [24]. The alloy exhibits 
good formability that is desirable for cold forming processes. Therefore, cold extrusion of the alloy is reasonable up to a true strain of 1.6 [1].

Table 1. The summary of extrusion experiments.

\begin{tabular}{|c|c|c|c|}
\hline $\begin{array}{c}\text { Initial } \\
\text { Workpiece } \\
\text { Diameter } \\
(\mathrm{mm})\end{array}$ & $\begin{array}{c}\text { Final } \\
\text { Workpiece } \\
\text { Diameter } \\
(\mathrm{mm})\end{array}$ & $\begin{array}{c}\text { Extrusion } \\
\text { Ratio }\end{array}$ & $\begin{array}{c}\text { True } \\
\text { Strain }\end{array}$ \\
\hline 25 & 17.62 & 1.42 & 0.7 \\
\hline 25 & 15.16 & 1.65 & 1 \\
\hline 25 & 12.41 & 2.01 & 1.4 \\
\hline
\end{tabular}

Table 2. Chemical composition of $16 \mathrm{MnCr} 5$ steel [24].

\begin{tabular}{|c|c|c|c|c|c|c|}
\hline \multicolumn{7}{|c|}{ Material 16MnCr5 } \\
\hline $\begin{array}{c}\text { Alloying } \\
\text { Element }\end{array}$ & $\mathrm{C}$ & $\begin{array}{c}\mathrm{Si} \\
\text { Max. }\end{array}$ & $\mathrm{Mn}$ & $\begin{array}{c}\mathrm{P} \\
\text { Max. }\end{array}$ & $\mathrm{S}$ & $\mathrm{Cr}$ \\
\hline $\begin{array}{c}\text { Percentage } \\
\text { by mass }\end{array}$ & $\begin{array}{c}0.14- \\
0.19\end{array}$ & 0.4 & $\begin{array}{c}1.00- \\
1.30\end{array}$ & 0.025 & $\leq 0.035$ & $\begin{array}{c}0.80- \\
1.10\end{array}$ \\
\hline
\end{tabular}

\section{CONTOUR CUT AND DATA PROCESSING}

For the determination of the axial stresses by the contour method, cutting must be performed so that mainly residual stresses in the axial direction of extruded specimens relax. Cutting was performed as shown in Figure 2(a) with a wire-EDM machine (Sodick ${ }^{\circledR}$ ) using $0.25 \mathrm{~mm}$ diameter brass wires. The extruded rods were firmly and discreetly clamped near the cut plane for straight cuts of all specimens as depicted in Figure 3(a)

using an appropriate apparatus to reduce cutting induced errors and plasticity. Furthermore, low power cutting settings which are a necessity for the implementation of the contour method were used as already discussed. Moreover, the apparatus helps that the specimens are aligned well without a tilt as flat as possible for a cut.

When a cut is finished, a little amount of ethyl alcohol is applied to cut surfaces to wipe away the traces of water after mounting off the specimen and both surfaces are dried using a dryer since flushing pure water in wireEDM process may cause degradation of the cut surface.

Surface contour scanning processes are carried out on the opposite cut surfaces of each specimen as indicated in
Figure 2(b) with an optical surface contour measurement system, Alicona ${ }^{\circledR}$ Infinite Focus G5. The system uses focus variation optical microscopy to measure both the geometry and roughness and has a $5 \mathrm{x}$ lens with vertical and lateral resolution up to $410 \mathrm{~nm}$ and $3.52 \mu \mathrm{m}$, respectively. Under these conditions, the system has a repeatability of $0.2 \mu \mathrm{m}$, which is accep-table for the current study.

This type of machine also could be more beneficial in terms of accuracy than mechanical coordinate measuring machines (CMM) while the measurements progress without an estab-lishment of contact between workpiece and measuring probe which will result in deformation [15]. After measurements of both the cut surfaces, a 3D data set in which the location of a point on the surface is expressed with $\mathrm{X}$ and $\mathrm{Y}$ coordinates and measured form (elastic deformation) in $\mathrm{Z}$ coordinate is obtained. Processing of measured data is carried out with main four steps: (1) Data alignment, (2) truncating, (3) smoothing and (4) curve fitting. Amongst these, data alignment is primary necessity to perform the ensuing averaging process of two opposite surfaces as the centres and coordinates of data sets after measurement of each surface are different on x-y horizontal plane (Figure 2). Therefore, the centres of data are moved to the origin on that plane using the mean values of each data set in X and $\mathrm{Y}$ directions by the help of a code in MatLab ${ }^{\circledR}$. A surface contour from the cut by wire-EDM process consists of surface roughness and waviness together with surface form [25].

Surface roughness and waviness that are produced during wire-EDM process will introduce inaccuracies in the measured data sets of the contour surfaces. However, data smoothing $[11,12]$ and curve fitting procedures of data processing are expected to mitigate these inaccuracies caused by surface roughness and waviness illustrated in Figure 4. The effect of plastic deformation is inevitably observed due to the narrowing thicknesses of the cylindrical specimens near edge as shown in Figure 5 whilst tensile residual stresses near surface after relaxation exert tremendous load as well as pressurized pure water in wire-EDM process.

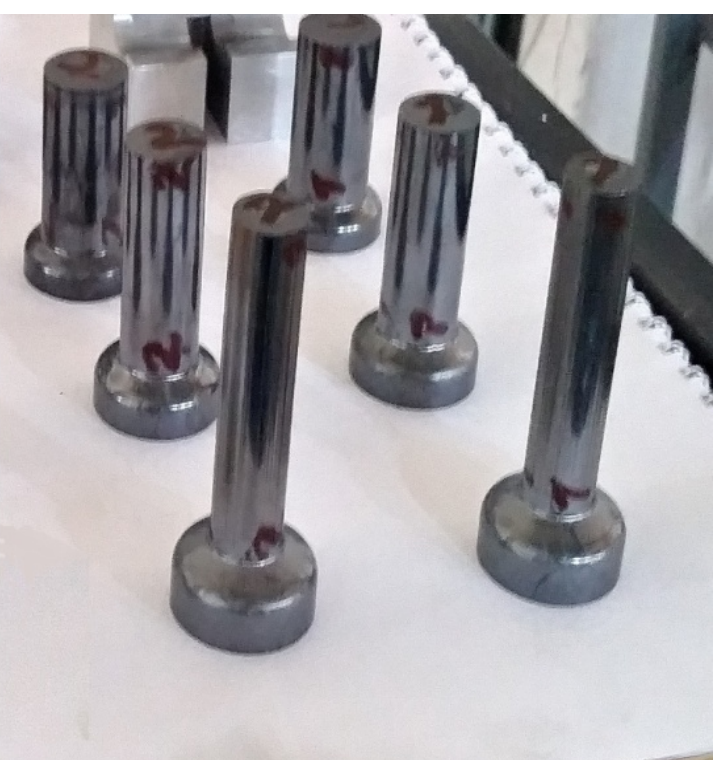

Figure 1. (a) an initial material and cold extruded specimens (b) the cold extruded specimens at three true strain 


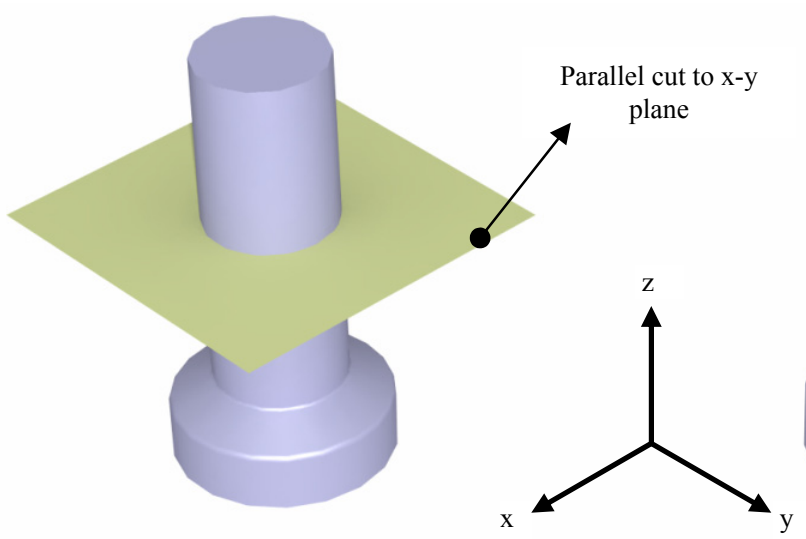

(a)

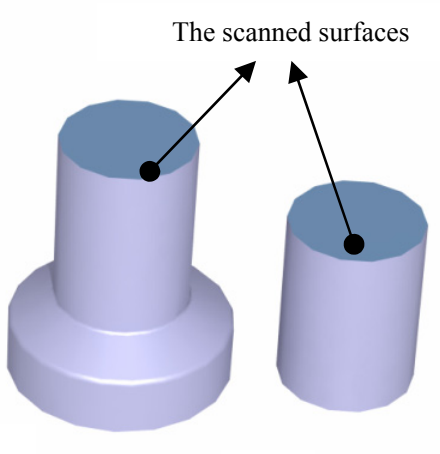

(b)

\section{Figure 2. (a) Specimen and the cutting plane (b) Contour measured surfaces}

As a result, the elimination of near-edge data becomes a necessity. Following to the first step, this procedure to remove distorted near edge data is carried out with another written code, individually. The removed region that is $1.0 \mathrm{~mm}$ in 1.4 true strained specimens and 1.2 $\mathrm{mm}$ in other specimens will be compensated by extrapolating the fit polynomial obtained by polynomial regression to the surface. While surface is symmetrical on both $\mathrm{Y}$ and $\mathrm{X}$ coordinates, the variations of axial residual stresses from centre to edge on cross-section on $\mathrm{x}-\mathrm{y}$ plane are expected to be the same and only change from centre to outer surface in the samples of axisymmetric cold extrusion process. Data processing for the contour method could normally be performed to obtain a three-dimensional fit surface to experimentally measured data without the assumption that axial residual stresses are axisymmetrically distributed around Z-axis as shown in Figure 2. Since the specimens possess full circular cross sections, it could lead to the misalignment of opposite surfaces and the huge number of data of the optical microscope used complicates the implementation of bivariate spline to create $3 \mathrm{D}$ fit surfaces for the calculation average of opposite faces. While the samples are fully circular in cross-section without any sharp edges, it is almost not possible to find the projection of a point in the opposite surface to implement the surface averaging procedure in order for the construction of 3D linear elastic models. The centres of opposite surfaces can easily be matched but one half of a specimen may be rotated around Z-axis. Therefore, it is not possible to match surfaces so as to calculate the average deformation in 3D linear elastic models. However, the variation of axial residual stresses is expected to develop symmetrically to any perpendicular plane to cross-section passing through the centre of circular cross-section and have been used widely in the previous researches and the results in good agreement with the experimental measures were obtained in the past $[14,25,26]$. During extrusion process with the press used in this study, the punch moves from up to down. That is, gravity is in the same direction as extrusion force while the process occurs perpendicular to ground.

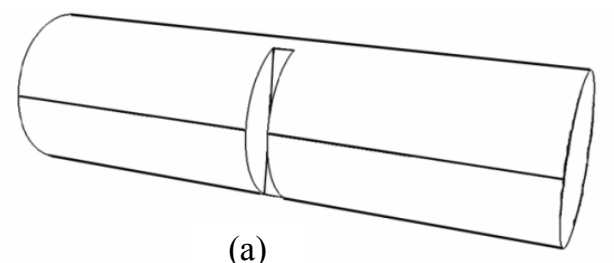

(a)

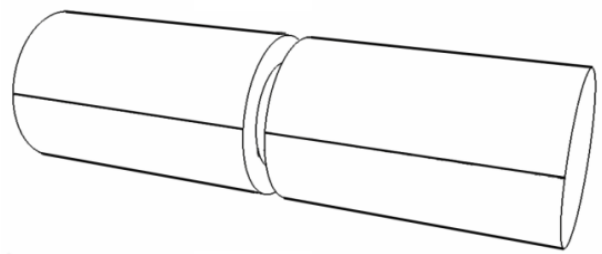

(b)

Figure 3. (a) The straight cut of the contour method (b) The circumferential cut

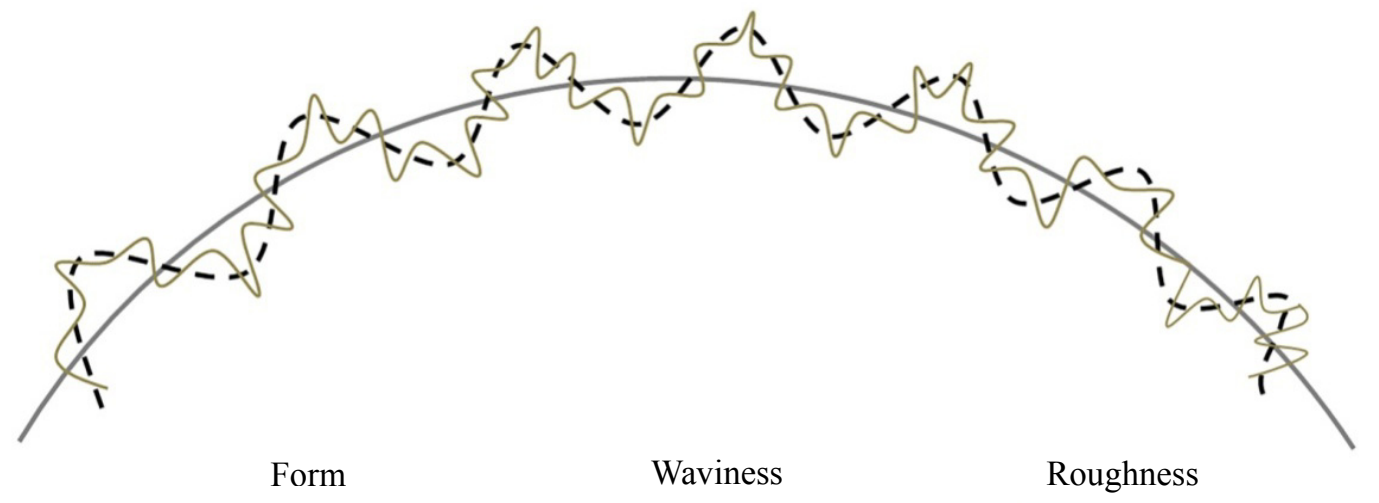

Figure 4. The illustration of surface adopted from 
As a result of these reasons, obtaining axial residual stresses as final 2D results that is varing from centre to edge is conducive approach for the investigation of the specimens used in the current study. As the optical microscopy produces tremendous amount of data for each contour surface, the approach reduced the amount of data and the effect of local defects (roughness and waviness) in the data. For this aim, data is divided into concentric shell with the intervals $(0.05 \mathrm{~mm})$ along radius and averaged in each shell in order to convert a $3 \mathrm{D}$ data set of each surface into $2 \mathrm{D}$ data set.

Consequently, the average deformation on each surface in each interval are obtained from the centre to the edge using a code in Matlab® software. Final data after data smoothing process includes the middle point in an interval (shell) radius versus average deformation in the interval in $\mathrm{Z}$ coordinate in the corresponding interval. For example, first shell near centre extends from origin to $0.05 \mathrm{~mm}$ radius. In this case, the middle

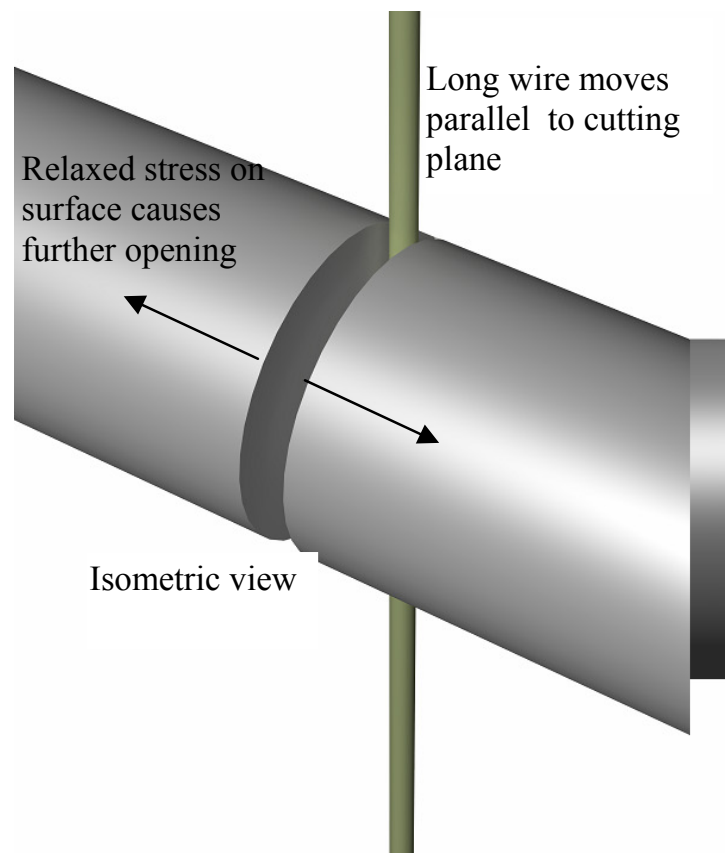

circle of first shell is at $0.025 \mathrm{~mm}$. The average deformation in this shell is the mean of all data points up to $0.05 \mathrm{~mm}$ radius from centre. However, this average deformation is not the mean deformation of opposite surfaces yet. The calculation of the average deformation of opposite surfaces is performed by using the mean deformation in the intervals on both opposite surfaces. Fit curves would be helpful to further reduce experimental noise and predict the deformation at eliminated locations near the edges. Moreover, this makes the implementation of boundary conditions in the FE models relatively simple. Fit curves for each specimen are constructed by the help of polynomial regression in Matlab ${ }^{\circledR}$ software. Finally, the polynomial curves in reverse sign are applied as displacement boundary condition in linear elastic FE model illustrated in Figure 6 using MSC Marc/Mentat ${ }^{\circledR}$ finite element package with the elasticity data of $210 \mathrm{GPa}$ and 0.3 , Young`s modulus and Poisson`s ratio, respectively.

\section{Relaxed rs in tension}

2. Pressurized water

Plastic deformation is expected in the narrow area.

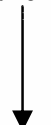

Figure 5. Schematical illustration of bulge effect in tensile form (Views are exaggerated)

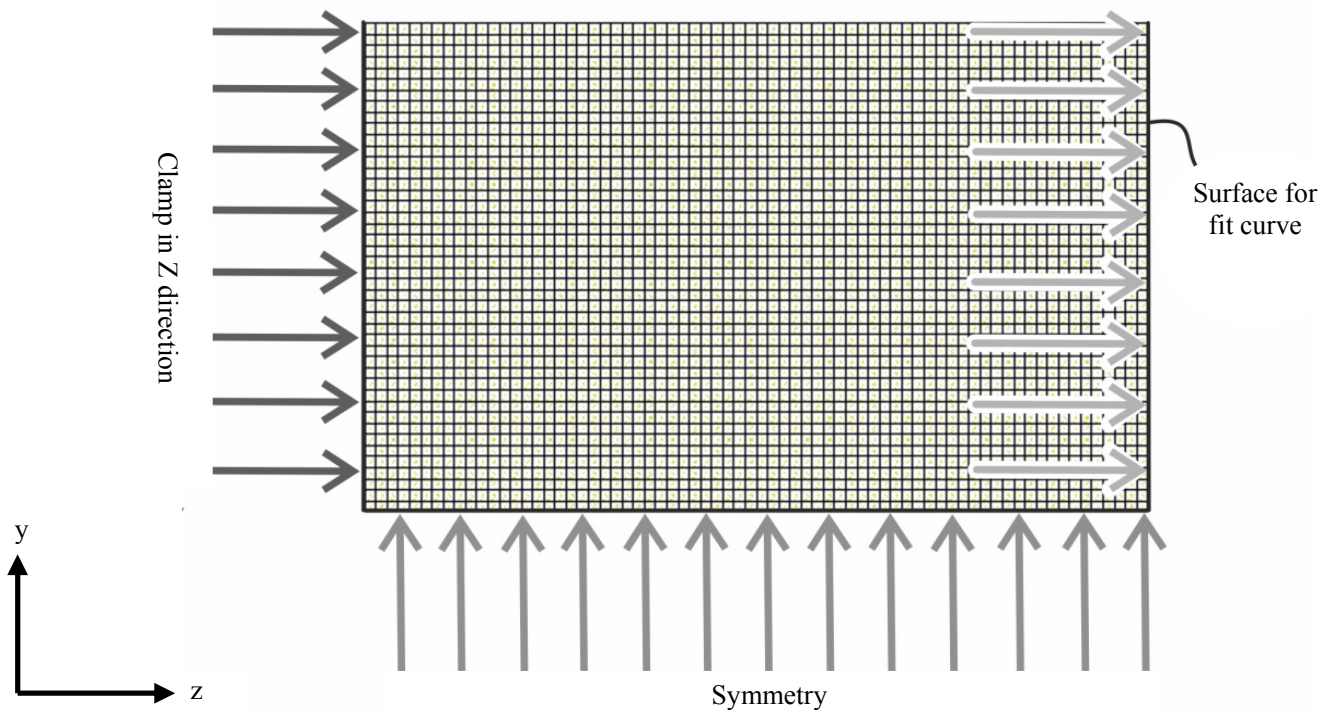

Figure 6. Boundary conditions for linear elastic FEA for the contour method using MSC Marc 


\section{FINITE ELEMENT ANALYSIS OF EXTRUSION PROCESS}

Two-dimensional axisymmetric models to simulate the manufacturing steps (extrusion and ejection) of steel rods with full circular cross-section are created in order for performing implicit type analyses using commercial software Abaqus ${ }^{\circledR}$. After mesh sensitivity study in descending die mesh size, 4-node bilinear stress/displacement elements [28], CAX4 in the size of $0.2 \mathrm{~mm}$ which reveal rather close stresses to smaller mesh sizes are used to mesh die and billet whose only halves are included in axisymmetric analyses. Stress and tempe-rature are computed independently with the use of stress /displacement elements [28]. Whereas 7875 elements exist on the billet, 985 elements are used on the die. Elastic material data for steel, Young's modulus and Poisson's ratio, for both die and billet are $210 \mathrm{GPa}$ and 0.3 , respectively. Coulomb friction rule with friction coefficient 0.05 which is appropriate for the lubricant, Molybdenum disulfide $\left(\mathrm{MoS}_{2}\right)$ in extrusion process is used [29]. An existing data for the hardening behaviour of the same material from the manufacturer in the university laboratory is used for the plastic behaviour of only the billet. The hardening curve in the FE simulation is illustrated in Figure 7 while the setup of whole full extrusion model is illustrated in Figure 8.

\section{RESULTS AND DISCUSSION}

In Figure 9-10, normalized radius, $r / R$, is used. $R$ corresponds to the final radii of workpieces whilst $r$ is the distance from the centres of cylinders. The observed stress profiles of all strains developing during punch forward movement show measurable similarity before ejection as depicted in Figure 9.

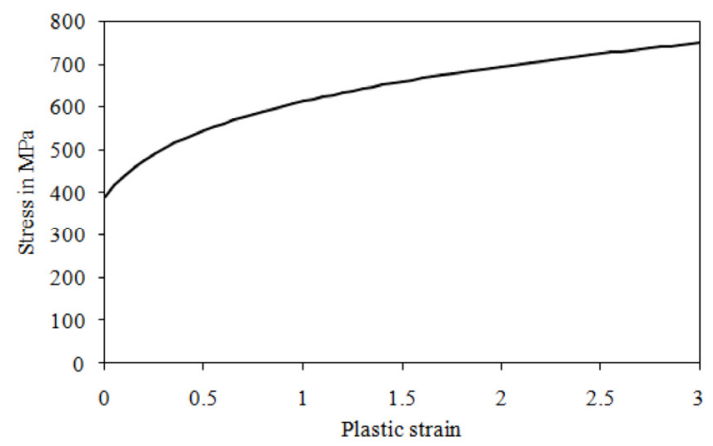

Figure 7. The hardening curve for $16 \mathrm{MnCr} 5$ used in the FE simulation of the cold extrusion process [30]

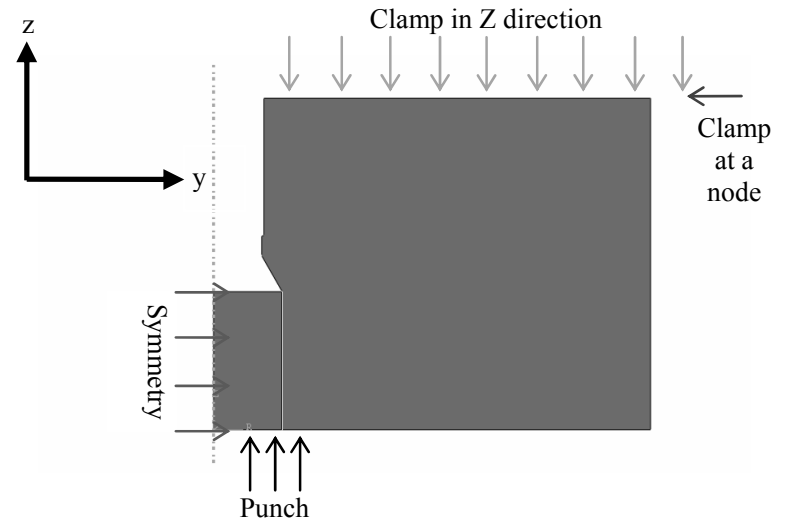

Figure 8. Illustration of full extrusion process Abaqus ${ }^{\circledR}$
The elastic deformation of die on horizontal x-y plane (the elastic deformation of die in the y direction in Figure 8 ) in die land area is greater in the case of 1.4 true strain than the others according to the finite element analyses (FEA) Abaqus ${ }^{\circledR}$. This can be attributed to larger extrusion force to push a billet in the same diameter through a die hole whose diameter is smaller for a higher extrusion ratio (higher true strain with the same initial diameter workpieces). In other words, 1.4 true-strained parts obtained from workpieces with the same initial diameter are more squeezed in die holes while die land area deforms elastically outward during press and inward during ejection. Die hole diameter expands only in the range of few micrometres and tightens back when punch force is removed. However, it must be stated that the effect of temperature and thermal softening during ejection is not predictable in the absence of the temperature-dependent hardening behaviour of the material with FEA.

In the regions near the cores of the rods in accordance with FEA and the contour method results, compressive residual stresses emerge in the specimens extruded to the true strains of 0.7 and 1.0 as demonstrated by Figure 10 . The centres of billets during pressing undergo constant stretching to which inner compressive residual stresses might be attributed [25]. Compressive stresses turn into stresses in tension toward outer surface after ejection ended. Surface tensile stresses may inevitably be affected by friction [25]. However, 1.4 true strained specimens depict different stress state in which a little amount of tensile stresses appear in core region. These tensile residual stresses might be caused due to the impact of ejection as described in the beginning of the section. In all of cases, compressive subsurface stresses are found, and surface stresses discovered through experiments are highly affected by plastic deformation and cutting conditions. The trends in the measurements are in agreement with the simulations. However, there are considerable differences at some local positions. But it is noteworthy that the main intention in this study is not performing FE simulations of extrusion process. The simulation results can certainly be improved with the rate-dependent and temperaturedependent material data as explained in the previous sections. Hence, the FE analyses also include errors and the results must be interpreted as qualitative rather than quantitative.

Axial residual stress distribution presented by Figure 10(a) compressive stresses exist in the interior part while tensile stresses emerge in the region close to surface according to the experiments and the FE analysis. The results of 0.7 strain analysis between the two experiments and numerical analysis differ. The curve of FE analysis may be more accurate than experiments since the relaxed surface could be distorted by cutting conditions. Numerical analysis generally tends to exhibit higher peak stresses compared to the experiments. Fig. 10(b) depicts residual stresses obtained from 1.0 true strain. Apparently, the maximum tensile stress reaches approximately $300 \mathrm{MPa}$. Compressive residual stresses of the experimental and $\mathrm{FE}$ analyses increase toward the core while stresses in the areas close to outer surface are more consistent. 
(a)

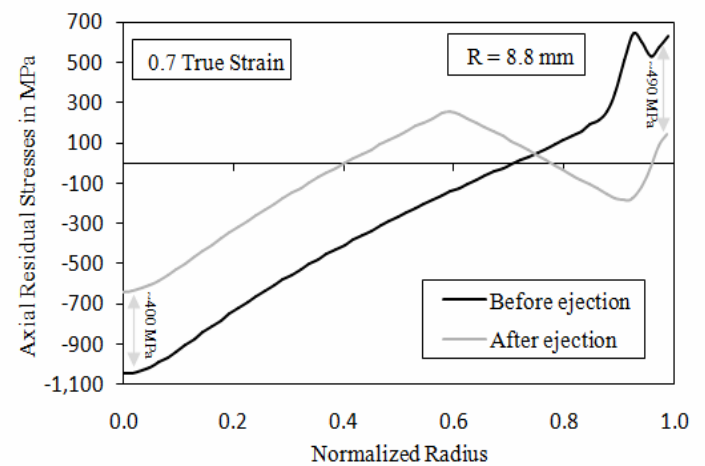

(b)

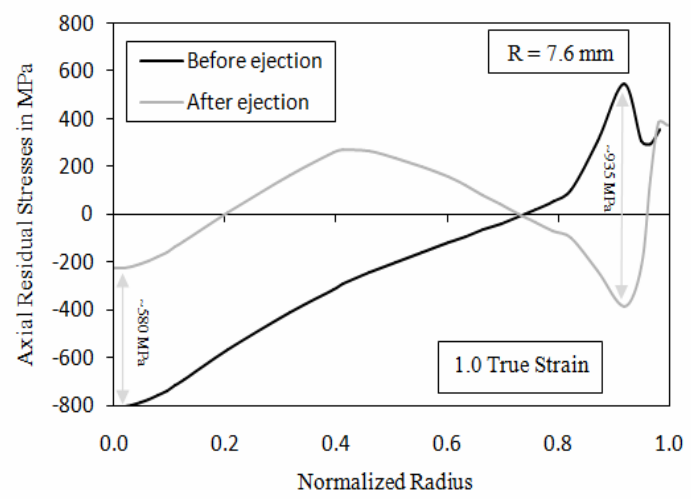

(c)

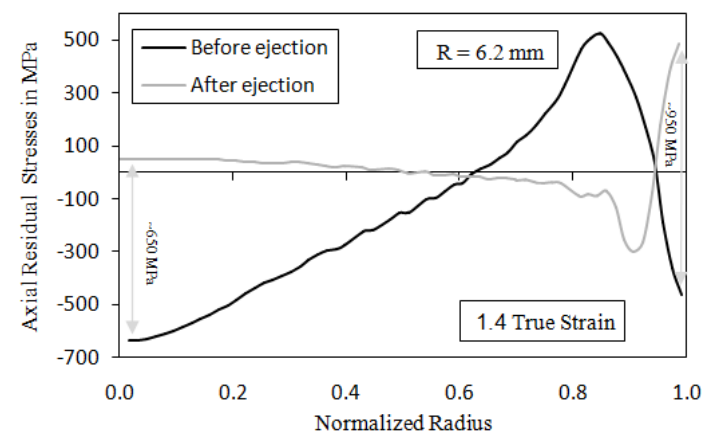

Figure 9. The distribution of axial residual stress according to full extrusion FEA in Abaqus ${ }^{\circledR}$

(a)

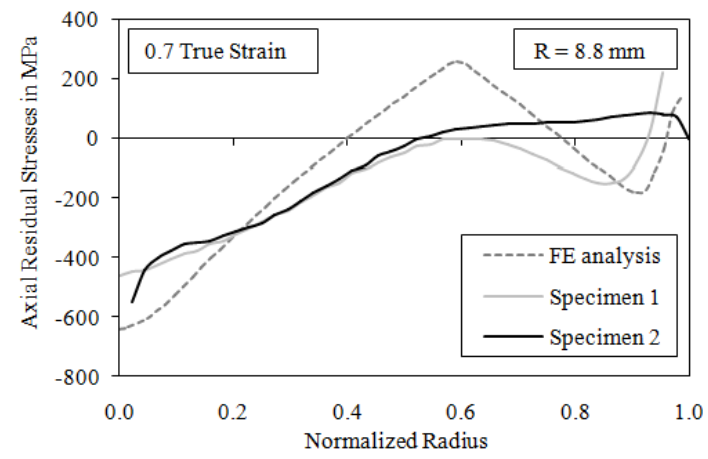

(b)

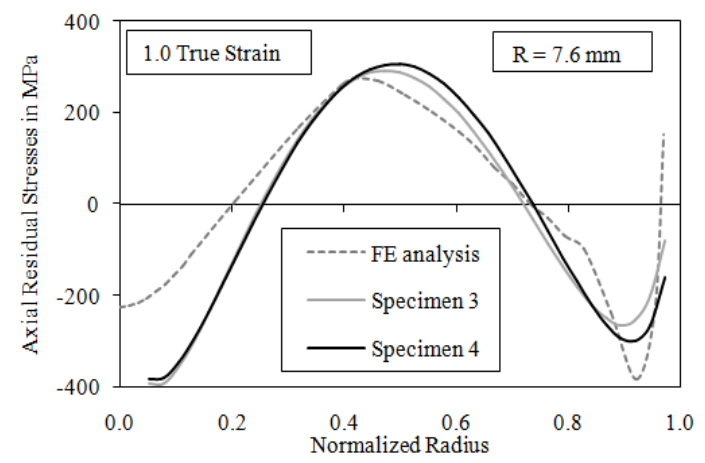

(c)

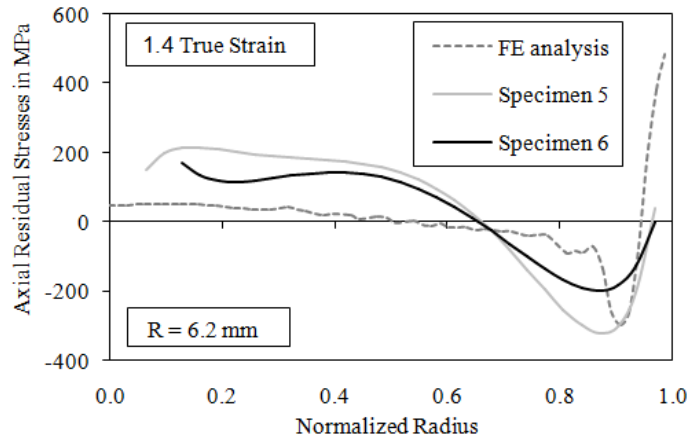

Figure 10. The comparison of the results of the contour method and FEA (Initial radii are 12.5 centimeters)

Figure 10(c) illustrates the results obtained from 1.4 true strained analyses. Contrary to lower strains, compressive residual stresses penetrate interior regions. The internal tensile stresses of 1.4 strained samples are generated particularly by the augmented elastic deformation in die after punch retraction. In general, compressive residual stresses are found inner regions whereas tensile residual stresses and high-stress gradients are distributed toward outer surface in three true strains in the present study. The agreement of stress profiles between numerical and experimental analyses is reasonable.

\section{CONCLUSION}

In this study, the axial residual stress distributions in cold extruded rods having 3 different extrusion ratios are obtained using the contour method. The surface contours of cut cross-sections are measured by the help of focus variation optical microscopy and the acquired data is processed and, subsequently, supplied to linear elastic FE model (the last procedure of the contour method). Aside from experimental measurements, full extrusion process is also simulated using another commercial FE package and it is found that the trends in the residual stresses are quite qualitatively similar. However, the rate-dependent and temperaturedependent hardening curve and more appropriate friction model would help to improve the FE analyses of full extrusion process to have a better qualitative agreement between the results, which is left out of the scope of this work. The experimental material tests could not be performed due to lack of necessary equipment.

Even though clamping was implemented with discreet care to clamp specimens closely to cutting plane, a specially designed clamping device which may improve further experimental results and exists in literature for various types of products except full cylindrical products could be still studied (plates [31]). Although the contour method seems to be an adequate method for the determination of axial residual stresses in cold metal forming applications, the validation of the results with neutron diffraction method could be valuable effort as an outlook of the current study. Another noteworthy finding of the present study could be that increased extrusion force with increasing strain may cause the alteration of stresses to grow during ejection while the elastic deformation (in the horizontal 
$\mathrm{x}-\mathrm{y}$ plane, Figure 8) of dies and its consequent plastic deformation caused by ejection is greater with higher strain in accordance with the full extrusion FE analyses.

\section{ACKNOWLEDGEMENT}

The first author is sincerely thankful to Mr. Yahya Tunc and all members of Metal Forming Centre of Excellence and Atilim University. Mr. Felix Kolpak, Prof. Dr.-Ing. habil. Dr.-Ing. E.h. K.-D. Bouzakis and Prof. Dr.-Ing. E.h. A. E. Tekkaya must be deeply thanked for the generous support. The special thanks are extended to Cetek Makina and ZWEZ Chemie $\mathrm{GmbH}$. Sincere thanks are owed to Mr. Tunc Sefa Altunsaray, Mr. Deniz Duran and Prof. Dr. Engin S. Kilic for their support. Lastly, the author is also thankful to TU Dortmund and Turkish-German University.

\section{CONFLICT OF INTEREST}

The author(s) declared no potential conflicts of interest with respect to the research, authorship, and publication of this article.

\section{REFERENCES}

[1] Lange K.: (1985) Handbook of metal forming. ISBN 0872634574, Society of Manufacturing Engi-neers, McGaw-Hill.

[2] Withers P.J., Bhadeshia H.K.D.H.: (2001) Residual stress part 2 - nature and origins, Materials Science and Technology, Vol. 17, No. 4, pp. 366-375, 2001.

[3] Kiran, B., Mishra, K., Singh, Y.R., Nagaraju, D.:Structural and Thermal Analysis of Butt Joint GTAW of Similar and Dissimilar Materials with Distinct Groove Angles Through Simulation and Mathematical Modelling. FME Transactions, Vol., 48, No. 3, pp. 667-680, 2020.

[4] Peric, M., Tonkovic, Z., Maksimovic, K.S., Stamenkovic, D.:Numerical Analysis of Residual Stresses in a T-Joint Fillet Weld Using a Submodeling Technique. FME Transactions, Vol. 47, No 1, pp. 183-189, 2019.

[5] Buljak, V., Maier, G.: Identification of residual stresses by instrumented elliptical indentation and inverse analysis. Mechanics Research Communications, 41, pp. 21-29, 2012.

[6] Peng, G., Lu, Z., Ma, Y., Feng, Y., Huan. Y., Zhang, T.: Spherical indentation method for estimating equibiaxial residual stress and elasticplastic properties of metals simultaneously. Journal of Materials Research, Vol. 33, No. 8, pp. 884-897, 2018.

[7] Bocciarelli, M., Maier, G.: Indentation and imprint mapping method for identificationmof residual stresses. Comput. Mater. Sci., Vol. 39, No.2, pp. 381-392, 2006.

[8] Wang, Z., Deng L., Zhao, J.: Estimation of residual stress of metal material without plastic plateau by using continuous spherical indentation. Int. J. of
Pressure Vessels and Piping, Vol. 172, pp. 373378, 2019.

[9] Prime, M.B.: (2001) Cross-sectional mapping of residual stresses by measuring the surface contour after a cut. J. Eng. Mater. Technol., Vol. 123, pp. 162-168.

[10]Bueckner, H.F.: The propagation of cracks and the energy of elastic deformation. Transaction of the ASME, Vol. 80, pp. 1225-1230, 1958.

[11] Prime, M.B.: (2009) The contour method: A new approach in experimental mechanics. Proceedings of the SEM Annual Conference 2009, New Mexico, USA, pp. 156.

[12]Prime, M.B., Kastengren A.L.: The contour method cutting assumption: Error minimization and correction. Experimental and Applied Mechanics, Vol. 6, pp. 233-250, 2011.

[13] Shin S.H.: FEM analysis of plasticity-induced error on measurement of welding residual stress by contour method. Journal of Mechanical Science and Technology 19(10), pp. 1885-1890, 2005.

[14] Tekkaya A.E., Gerhardt J., Burgdorf M.: Residual stresses in cold-formed workpieces. Annals of the CIRP Vol. 34, pp. 225-230, 1985.

[15] Prime, M.B., Sebring, R.J., Edwards, J.M., Hughes, D.J., Webster, P.J.: Laser surfacecontouring and spline data-smoothing for residual stress measurement. Society for Experimental Mechanics Vol. 44, No. 2, pp. 176-184, 2004.

[16] Hosseinzadeh, F., Kawal J., Bouchard, P.J.: Towards good practice guidelines for contour method of residual stress measurement. The Journal of Engineering, Vol. 2014, No. 8, pp. 453468, 2014.

[17] Pollard, J.D., Brahimi, S., Watford, A., Jackson, M., Wynne, B.P.: 2016. The determination of residual stress in extruded Ti-6Al-4V by contour method and finite element analysis. Proceedings of the 13th World Conference on Titanium, pp. 305-310.

[18] Prime, M.B., Newborn, M.A., Balog, J.A.: Quenching and cold-work residual stresses in aluminum hand forgings: Contour measurement and FEM prediction. Material Science Forum Vols., pp. 435-440, 2003.

[19]DeWald, A.T., Hill M.R.: Multi-Axial Contour Method for Mapping Residual Stresses in Continuously Processed Bodies. Experimental Mechanics Vol. 46, 473, 2006.

[20]Kartal, M.E., Liljedahl, C.D.M., Gungor, S., Edwards, L., Fitzpatrick, M.E.: Determination of the Profile of the Complete Residual Stress Tensor in a VPPA Weld Using the Multi-Axial Contour method. Acta Materialia, Vol. 56, No. 16, pp. 4417-4428, 2008.

[21] Pagliaro, P., Prime, M.B., Swenson, H., Zuccarello B.: Measuring Multiple Residual Stress Components using the Contour Method and Multiple Cuts. Experimental Mechanics Vol. 50, pp. 187194, 2010. 
22] Pagliaro, P., Prime, M.B., Robinson, J.S., Clausen, B., Swenson, H., Steinzig, M., Zuccarello B.: Measuring Inaccessible Residual Stresses Using Multiple Methods and Superposition. Experimental Mechanics Vol. 51, pp.1123-1134, 2011.

[23] Harichard, Chaturvedi, S, Sharma, S.: 2012. Optimization of heat treatment process. International Journal of Engineering Science and Technology, Vol. 4, No. 3, pp. 998-1004.

[24] DIN EN 10084 Standards (2008), Case hardening steels - technical delivery conditions. DIN 10084:2008-06.

[25] Whitehouse, D.J.: 2011. Handbook of surface and nanometrology. Taylor Francis, 2nd Edition, pp. 63, 2011.

[26] Pyzalla A., Reimers W.: Residual stress and texture due to cold and hot extrusion processes. Textures, Stress and Microstructures, Vol. 33, pp. 291-301, 1999.

[27]Cheng, W., Finnie, I.: A New Method for Measurement of Residual Axial Stresses Applied to a Multi-Pass Butt-Welded Cylinder. Journal of Engineering Materials and Technology, Vol. 109, No. 4, 337.

[28] Abaqus 6.11 Abaqus/CAE user`s manual 2011.

[29] Bay, N.: The state of the art in cold forging lubrication. Journal of Materials Processing Technology, Vol. 46, No. 1-2, pp. 19-40, 1994.

[30] Simsir, C., Duran, D.: A flow stress model for steel in cold forging process range and the associated method for parameter identification. International Journal Advance Manufacturing Technology, Vol. 94, pp. 3795 - 3808, 2018.

[31] Traore, Y., Bouchard, P.J., Francis, J., Hosseinzadeh, F.: A Novel Cutting Strategy For
Reducing Plasticity Induced Errors In Residual Stress Measurements Made with The Contour Method, Proceedings of the ASME 2011 Pressure Vessels \& Piping Division Conference PVP2011.

\section{КОНТУРНИ МЕТОД У ОДРЕЪИВАЊУ АКСИЈАЛНИХ РЕЗИДУАЛНИХ НАПОНА КОД ХЛАДНО ЕКСТРУДИРАНИХ ЧЕЛИЧНИХ ШИПКИ}

\section{О.Ајдин, Ц.Симсир}

Резидуални напони код хладно екструдираних делова су од значаја за век трајања и производне перформансе дела. Када се хладно екструдирани део користи непосредно, његов век трајања зависи од резидуалних напона насталих у току хладног истискивања. Ако се део машински обрађује после истискивања, може доћи до појаве дисторзије. Постоји само неколико метода за мерење аксијалних резидуалних напона код пуних цилиндричних дебелих компонената масивног обликовања. Како су високо-енергетски методи рендгенског зрачења и неутронске дифракције мање доступни и скупи, метод контуре за тачну процену резидуалних напона може бити алтернатива. Заостали напони код екструдираних челичних шипки су у овом раду одређени применом метода контуре за различите односе истискивања. Такође је извршена анализа коначних елемената за исте услове у циљу упоређивања са методом контуре. Резултати показују да је метод контуре драгоцени кандидат за мерење аксијалних резидуалних напона код хладно екструдираних дебелих компонената. 